\title{
A TEST FOR SPACE CLUSTERING AND ITS APPLICATION TO CONGENITAL LIMB DEFECTS IN CARDIFF
}

\author{
SETSUKO LLOYD AND C. J. ROBERTS \\ Department of Social and Occupational Medicine, The Welsh National School of Medicine, Cardiff
}

\begin{abstract}
Several methods are currently available for investigation of low intensity space-time clustering (Knox, 1963, 1964; Ederer, Myers, and Mantel, 1964; David and Barton, 1966; Mantel, 1967; Pike and Smith, 1968.) Its presence usually indicates one of two causes-either an infection or a causal factor which is local in both time and space and experienced by each individual in the cluster. There are, however, other situations in epidemiology where the effect of either time alone or space alone is localized. An annual cyclic trend is an example of the former; similarly, a condition localized only in space could exist without 'outbreaks' in the time period concerned. Admittedly if another time period in the same area were to be considered the spatial clusters might no longer exist, and in this sense we may still be considering the space-time problem. However, the main interest in this paper is a pattern in which the time component of clusters is so small that it becomes irrelevant to the analysis.
\end{abstract}

The study of spatial patterns of a disease in a given area necessarily involves the population at risk. The problem is trivial if the number of cases is large and the area already divided into well-defined sub-areas whose populations are known. Analysis and subsequent interpretation is difficult when the number of observed cases with the disease is relatively small, yet on visual inspection there appears to be spatial clustering. Notified limb defects (syndactyly, polydactyly, and reduction deformities) born in Cardiff between 1964 and 1966 exhibited these characteristics, and this paper presents the outcome of their analysis, primarily in respect of spatial clustering, but also with brief reference to time-clustering and space-time interaction.

\section{SOURCES OF DATA}

For the three years beginning 1 January 1964 information was collected on all infants born to women resident in two counties in South Wales (Glamorgan and Monmouthshire) and on all the congenital defects identified in that population. The notification of congenital defects was received from four sources-birth notification cards, congenital defect notification forms received from various consultants, hospital diagnostic records, and stillbirth and death registrations. More detailed descriptions of the method and the results of preliminary investigations can be found elsewhere (Richards and Lowe, 1971).

Although it would be unrealistic to consider all limb defects in isolation (because of their frequent coexistence with other malformations and skeletal deformities) there is a group of defects usually confined to the limbs which, although not necessarily of major clinical importance, is of considerable interest in the context of embryology and human physiology. This group consists of polydactylyo syndactyly, and reduction deformities. We decided to investigate all such defects born in Cardie during the period of the survey (Table I). For clarity of analysis only the data from singleton births $(n=14,451)$ have been used. At the time of the survey Cardiff had a population of around 250,000 living within an area of approximately 36 square miles $\left(93 \mathrm{~km}^{2}\right)$.

\section{RESULTS}

\section{Distribution in SPACE}

The distribution of the population at risk within the study has to be considered before the observation of apparent spatial clustering on visual inspection alone can be interpreted. In the present study, for example, the population at risk (total births) was found to cluster in space because of variable

TABLE I

CATEGORIES OF LIMB DEFECTS (CARDIFF BIRTHS 1964-66) USED IN SPACE-CLUSTERING ANALYSIS

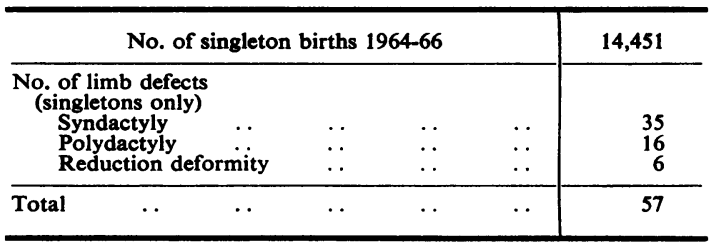


TABLE II

FREQUENCY DISTRIBUTION OF ALL POSSIBLE PAIRS (LIMB DEFECTS AND RANDOM SAMPLES) BY DISTANCE

\begin{tabular}{|c|c|c|c|c|c|c|c|c|c|}
\hline & & & $d<1$ & $1 \leqslant d<2$ & $\begin{array}{l}\text { Distance in } \\
\mathbf{2} \leqslant \mathrm{d}<3\end{array}$ & $\begin{array}{l}0 \text { Metres (d) } \\
3 \leqslant d<4\end{array}$ & $4 \leqslant d<10$ & $d \geqslant 10$ & Total \\
\hline Limb cases & .. & .. & 5 & 11 & 12 & 12 & 73 & 1,483 & 1,596 \\
\hline $\begin{array}{l}\text { Random sample } 1 \\
\text { Random sample } 2 \\
\text { Random sample } 3 \\
\text { Random sample } 4 \\
\text { Random sample } 5\end{array}$ & $\begin{array}{l}\cdots \\
\cdots \\
\cdots\end{array}$ & $\begin{array}{l}\ddot{x} \\
\ddot{*} \\
\ddot{*}\end{array}$ & $\begin{array}{l}6 \\
2 \\
5 \\
2 \\
0\end{array}$ & $\begin{array}{l}4 \\
5 \\
7 \\
5 \\
5\end{array}$ & $\begin{array}{l}4 \\
8 \\
8 \\
6 \\
4\end{array}$ & $\begin{array}{r}12 \\
10 \\
6 \\
16 \\
11\end{array}$ & $\begin{array}{r}97 \\
106 \\
115 \\
76 \\
117\end{array}$ & $\begin{array}{l}1,473 \\
1,465 \\
1,455 \\
1,491 \\
1,459\end{array}$ & $\begin{array}{l}1,596 \\
1,596 \\
1,596 \\
1,596 \\
1,596\end{array}$ \\
\hline
\end{tabular}

population density and fertility. We overcame this problem by taking repeated sets of random samples from the pool of all singleton births in Cardiff for the same time period, the size of each sample being equal to that of the limb defects series (i.e., $n=57$ ). $\mathrm{X}$ and $\mathrm{Y}$ coordinates were then estimated to the nearest $\mathbf{1 0}$ metres by the address of the mother for each limb defect case and each random sample subject. The distribution of distances for all possible pairs was then obtained for each set of cases as in Knox's method (Knox, 1963, 1964) and the number of pairs within various distance criteria for the limb defects was compared with the mean number of pairs satisfying the same criteria from the random samples. Significant values were calculated assuming that the null distribution is Poisson with this mean.

A difficulty at this stage was the absence of a basis on which to establish what critical values should be used for analysis. We decided to examine the distribution of distances for limb defects and five random samples by various intervals (Table II). For the intervals of 100 up to $200 \mathrm{~m}$ and 200 up to $300 \mathrm{~m}$ the number of pairs for limb defects is greater than any of the random samples, and the intervals either side of these suggest a somewhat diluted version of the same effect. This excess number of pairs of limb defects for 100 up to $300 \mathrm{~m}$ has been 'made up' in the interval of 400 up to $1,000 \mathrm{~m}$ by a deficiency of pairs for limb defects.

TABLE III

NUMBERS OF PAIRS BY CRITICAL DISTANCES AND SIGNIFICANCE VALUES (ASSUMING POISSON)

\begin{tabular}{|c|c|c|c|c|c|}
\hline & & \multicolumn{4}{|c|}{ Distance in 100 Metres (d) } \\
\hline & & $d<2$ & $\mathbf{d}<3$ & $d<4$ & $d<5$ \\
\hline Limb cases & . & 16 & 28 & 40 & 48 \\
\hline $\begin{array}{l}\text { Random sample } 1 \\
\text { Random sample } 2 \\
\text { Random sample } 3 \\
\text { Random sample } 4 \\
\text { Random sample } 5\end{array}$ & $\begin{array}{l}\because \\
\because \\
\cdots \\
\cdots\end{array}$ & $\begin{array}{r}10 \\
7 \\
12 \\
7 \\
5\end{array}$ & $\begin{array}{r}14 \\
15 \\
20 \\
13 \\
9\end{array}$ & $\begin{array}{l}26 \\
25 \\
26 \\
29 \\
20\end{array}$ & $\begin{array}{l}38 \\
45 \\
39 \\
36 \\
30\end{array}$ \\
\hline $\begin{array}{l}\text { Mean of random samples } \\
\text { (Sample variance) ... }\end{array}$ & $\therefore$ & $\begin{array}{c}8 \cdot 2 \\
(6 \cdot 2)\end{array}$ & $\begin{array}{l}14 \cdot 2 \\
(12 \cdot 6)\end{array}$ & $\begin{array}{l}25 \cdot 2 \\
(8 \cdot 6)\end{array}$ & $\begin{array}{r}37 \cdot 6 \\
(23 \cdot 4)\end{array}$ \\
\hline . & . & 0.015 & 0.0001 & 0.0008 & 0.046 \\
\hline
\end{tabular}

Table III gives the number of pairs less than specified distances derived from the figures in Table II. An attempt was made to give significance values to the observed number of limb defect pairs. A critical value of up to 300 metres gives the most significant result although other values in the table are also significant. The appropriateness of the Poisson distribution used here cannot be tested properly without further random samples to test the goodness of fit; this was not done in this study as the process of finding $X$ and $Y$ coordinates for a further series of addresses in Cardiff would have been too time-consuming without computerization. However, the sample variances give no evidence to suggest that the stated significance levels are unduly high as the variances are all smaller than the corresponding sample means.

\section{Distribution IN TIME}

Knox (1964) has formulated a null distribution of time intervals for independent observation of pairs in a given time period. As all possible pairs cannot be considered as independent observations, a Monte Carlo procedure similar to the one used to determine the above spatial distribution was used, i.e., repeated sets of 57 dates were picked at random from the three-year period and the distribution of time intervals for all possible pairs of limb defects (by the date of last menstrual period) was compared with that of random samples in a similar manner to that for spatial distribution.

Table IV gives the distribution of time intervals of all possible pairs for limb defects and random samples. The numbers of pairs for various time intervals predicted by Knox's procedure (triangular distribution) are also given and they correspond very well to those predicted by the Monte Carlo procedure. The findings provide no evidence for clustering in time.

\section{SPACE AND TIME INTERACTION}

Finally, a brief analysis was made of space-time interaction using Knox's method to see if those pairs close in space were also close in time. 
TABLE IV

FREQUENCY DISTRIBUTION OF ALL POSSIBLE PAIRS (LIMB DEFECTS AND RANDOM SAMPLES) BY TIME INTERVALS

\begin{tabular}{|c|c|c|c|c|c|c|c|}
\hline & \multicolumn{7}{|c|}{ Time Interval $(t)$ in Days } \\
\hline & $0-10$ & $11-20$ & $21-40$ & $41-80$ & $81-160$ & $161-320$ & $321+$ \\
\hline Limb cases & 34 & 21 & 41 & 106 & 211 & 374 & 809 \\
\hline $\begin{array}{l}\text { Random sample } 1 \\
\text { Random sample } 2 \\
\text { Random sample } 3 \\
\text { Random sample } 4 \\
\text { Random sample } 5\end{array}$ & $\begin{array}{l}33 \\
27 \\
35 \\
36 \\
23\end{array}$ & $\begin{array}{l}26 \\
28 \\
23 \\
25 \\
24\end{array}$ & $\begin{array}{l}51 \\
45 \\
54 \\
62 \\
56\end{array}$ & $\begin{array}{l}120 \\
123 \\
104 \\
114 \\
118\end{array}$ & $\begin{array}{l}199 \\
220 \\
211 \\
213 \\
218\end{array}$ & $\begin{array}{l}320 \\
402 \\
362 \\
405 \\
413\end{array}$ & $\begin{array}{l}847 \\
751 \\
807 \\
741 \\
744\end{array}$ \\
\hline Mean of random samples & $30 \cdot 8$ & $25 \cdot 2$ & $53 \cdot 6$ & $115 \cdot 8$ & $212 \cdot 2$ & $380 \cdot 4$ & $778 \cdot 0$ \\
\hline $\begin{array}{l}\text { Prediction by Knox's } \\
\text { formula }\end{array}$ & 30 & 29 & 57 & 110 & 207 & 364 & 799 \\
\hline
\end{tabular}

TABLE V

FREQUENCY DISTRIBUTION OF ALL POSSIBLE PAIRS OF LIMB DEFECTS BY SPECIFIED TIME AND DISTANCE INTERVALS

\begin{tabular}{|c|c|c|c|c|c|c|c|c|c|}
\hline \multirow[b]{2}{*}{ Time in days } & & & & \multicolumn{4}{|c|}{ Distance in 100 Metres (d) } & \multirow[b]{2}{*}{ Total } & \multirow{2}{*}{$\begin{array}{l}\% \text { less than } \\
500 \text { metres }\end{array}$} \\
\hline & & & & $5 \leqslant d$ & $5<d \leqslant 10$ & $10<d \leqslant 20$ & $d>20$ & & \\
\hline $\begin{array}{ll}0-80 & . . \\
81-160 & . \\
161-320 & . \\
321 \text { and over } . .\end{array}$ & $\begin{array}{l}\cdots \\
\cdots \\
\cdots\end{array}$ & $\begin{array}{l}\cdots \\
\cdots \\
\cdots\end{array}$ & $\begin{array}{l}\cdots \\
\cdots \\
\cdots\end{array}$ & $\begin{array}{c}10^{*} \\
8 \\
12 \\
22\end{array}$ & $\begin{array}{r}7 \\
8 \\
16 \\
30\end{array}$ & $\begin{array}{r}24 \\
32 \\
58 \\
118\end{array}$ & $\begin{array}{l}161 \\
163 \\
288 \\
639\end{array}$ & $\begin{array}{l}202 \\
211 \\
374 \\
809\end{array}$ & $\begin{array}{l}5 \cdot 0 \\
3 \cdot 8 \\
3 \cdot 2 \\
2 \cdot 7\end{array}$ \\
\hline Total & . & . & $\cdots$ & 52 & 61 & 232 & 1,251 & 1,596 & $3 \cdot 3$ \\
\hline$\%$ less than 80 days & . & .. & $\ldots$ & $19 \cdot 2$ & $11 \cdot 5$ & $10 \cdot 3$ & $12 \cdot 9$ & $12 \cdot 7$ & \\
\hline
\end{tabular}

Expected No. 6.6; $P=0.1$

Finer intervals less than 80 days and $500 \mathrm{~m}$ were also considered, but it was decided to combine these intervals as the entries were so sparse.

Table $\mathrm{V}$ gives the distribution of all possible pairs of limb defects by specified time and distance intervals. Here again we have no prior knowledge of the critical values and it is necessary to look at various combinations of time and space intervals. The proportion of pairs less than 80 days for various distance intervals suggests an interaction, and so does the proportion of pairs less than $\mathbf{5 0 0}$ metres for various time intervals. By Knox's method, however, none of the combinations of critical values gave significant results-the smallest $P$ value of 0.1 by permutational approach was obtained when $d=$ 500 metres and $t=80$ days. The $P$ value for this combination obtained by Poisson distribution with the mean of $6.6(202 \times 50 / 1596)$ was also approximately $0 \cdot 1$.

\section{Discussion}

The cause of the spatial clustering observed in this study is not immediately obvious, and the test itself cannot distinguish between genetic and environmental causes of the phenomenon. Environmental factors related to socio-economic status (e.g., housing and income) are an unlikely explanation of the observed distribution since although the controls were not matched for social class, there was no evidence of any association between social class and limb defects (Table VI).

It is said that polydactyly is common in Africans (Norman, 1963; Stevenson, Johnston, Stewart, and Golding, 1966). Polydactyly alone and syndactyly alone can occur in families, and in such cases the mode of inheritance is generally thought to be a simple dominant gene. But sporadic cases of both

TABLE VI

LIMB DEFECTS (CARDIFF 1964-66) BY SOCIAL CLASS

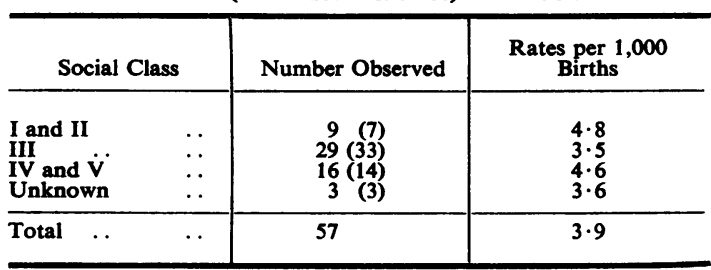

N.B. The numbers in parentheses are expected numbers, assuming there is no relationship by social class.

$x_{[3]}^{2}=1 \cdot 34 \mathrm{NS}$ 
(particularly the former) are not at all uncommon (Stevenson et al., 1966) and in such cases the genetic contribution is unknown.

We traced 41 of the 57 notified cases and 21 $(51 \%)$ reported a family history of limb defects. Eight mothers reported that the child's ethnic origin was non-European. It was also stated that five of the 16 cases of polydactyly came from one general practitioner's list. At the time of the study there were approximately 130 general practitioners in Cardiff and if we assume that their list sizes were the same the likelihood of this happening by chance alone is approximately 1 in 50,000 . Although none of the five cases was born within 500 metres of each other, four out of the five reported a family history of limb defects. It therefore seems likely that the findings observed in this study are caused by ethnic factors, since families with similar genes, religions, and other common interests are more likely to live close to one another than those with no ethnic ties.

\section{SUMMARY}

Visual inspection of the distribution of place of residence of infants with limb defects born in Cardiff between 1964 and 1966 suggested spatial clustering. The problem of determining, in some systematic way, whether these apparent spatial clusters could have arisen by chance was approached as follows. Five sets of random samples of births were taken (each of the same size as the limb defects group) and the number of pairs less than 200 metres, 300 metres, 400 metres, and 500 metres apart were calculated for the limb defects group and for each of the random samples. A significant value was given to the observed number of pairs of limb defects satisfying each of the critical distances, assuming that its null distribution is Poisson with a mean estimated by the mean number of pairs of random samples satisfying the same critical distance. For all the values of critical distances the test was significant.
We acknowledge with gratitude the generous grant from the Association for the Aid of Crippled Children, New York, which made this investigation possible. We wish to acknowledge the invaluable assistance given by Dr. D. Anderson, Medical Officer of Health, Cardiff, and it is with pleasure that we also acknowledge our indebtedness to the Medical Officers of Health of Merthyr Tydfil, Newport, Swansea, Glamorgan, and Monmouthshire for their interest and co-operation and to the many consultant obstetricians, paediatricians, pathologists, dermatologists, and orthopaedic, plastic, and ophthalmic surgeons who have notified and continue to notify to us the names of infants in our birth population who have come to their attention with congenital defects.

\section{REFERENCES}

David, F. N., and Barton, D. E. (1966). Two spacetime interaction tests for epidemicity. Brit. J. prev. soc. Med., 20, 44.

Ederer, F., Myers, M. H., and MANTel, N. (1964). A statistical problem in space and time: Do leukemia cases come in clusters? Biometrics, 20, 626.

KNOX, G. (1963). Detection of low intensity epidemicity. Application to cleft lip and palate. Brit. J. prev. soc. Med., 17, 121.

- (1964). The detection of space-time interactions. Appl. Statist., 13, 25.

Pike, M. C., and SMIth, P. G. (1968). Disease clustering: A generalization of Knox's approach to the detection of space-time interactions. Biometrics, 24, 541.

MANTEL, N. (1967). The detection of disease clustering and a generalized regression approach. Cancer Res., 27, 209.

NoRman, A. P. (1963). Congenital Abnormalities in Infancy. Blackwell Scientific Publications, Oxford.

Richards, I. D. G., and Lowe, C. R. (1971). Incidence of congenital defects in South Wales, 1964-66. Brit. J. prev. soc. Med., $25,59$.

Stevenson, A. C., Johnston, H. A., Stewart, M. I. P., and GoldING, D. R. (1966). Congenital Malformations: $A$ Report of a Study of Series of Consecutive Births in 24 Centres. Bull. Wld Hlth Org., 34, Supplement. 